Check for updates

Cite this: RSC Adv., 2017, 7, 28637

Received 11th April 2017

Accepted 12th May 2017

DOI: $10.1039 / \mathrm{c} 7 \mathrm{ra04122e}$

rsc.li/rsc-advances

\title{
A multianalyte fluorescent carbon dots sensing system constructed based on specific recognition of $\mathrm{Fe}(\mathrm{III})$ ions $\dagger$
}

\author{
Pei Song, (D) ${ }^{a}$ Lisha Zhang, ${ }^{a}$ Hao Long, ${ }^{a}$ Meng Meng, ${ }^{a}$ Ting Liu, ${ }^{b}$ Yongmei Yin ${ }^{\star a}$ \\ and Rimo $\mathrm{Xi}^{\star a}$
}

In this research, we developed a multianalyte fluorescence sensing system through a carbon dots (CDs)based fluorescent probe that can specifically recognize Fe(III) by fluorescence quenching. The CDs prepared using black tea by a hydrothermal method show outstanding properties like low cytotoxicity, high photostability, excellent biocompatibility, and high sensitivity. It was found that the fluorescence of CDs can be quenched by micromolar concentrations of $\mathrm{Fe}(\mathrm{III})$ in both aqueous solutions as well as living cells. It is well known that glucose can be oxidized by glucose oxidase (GOx) to release $\mathrm{H}_{2} \mathrm{O}_{2}$, which, in turn, can oxidize $\mathrm{Fe}(\mathrm{II})$ to $\mathrm{Fe}(\mathrm{III})$. Based on this consideration, a multianalyte sensing system was established. Therefore the quantitative analysis of $\mathrm{Fe}(\mathrm{III}), \mathrm{H}_{2} \mathrm{O}_{2}$, and glucose with detection limits of 0.25 $\mu \mathrm{M}, 0.82 \mu \mathrm{M}$, and $1.71 \mu \mathrm{M}$, respectively, was achieved by the simple and cost-effective multianalyte CDs sensing system constructed. The sensing system showed high photostability and negligible cytotoxicity toward HeLa cells, which enables it to be applied in the visualization of Fe(III) or $\mathrm{H}_{2} \mathrm{O}_{2}$ in living cells. The system was further applied in the detection of $\mathrm{Fe}(\mathrm{III})$ or glucose in human serum, and satisfactory results were obtained.

\section{Introduction}

As the most abundant transition metal ion in cellular systems, ferric ions perform crucial roles in biological systems involved in enzyme catalysis, cellular metabolism, oxygen transport in hemoglobin, and as a cofactor in enzyme-based reactions. ${ }^{1-5}$ Iron overload and deficiency can disturb cellular homeostasis and give rise to various diseases resulting from biological disorders, such as anemia, ${ }^{6}$ dysfunction of kidney ${ }^{7,8}$ and liver, ${ }^{9,10}$ arthritis, Alzheimer's disease, ${ }^{11,12}$ heart failure, diabetes, and cancer. ${ }^{13,14}$ Therefore, the determination of $\mathrm{Fe}(\mathrm{III})$ is of great significance for early diagnoses of these diseases. Among the various strategies for $\mathrm{Fe}(\mathrm{III})$ sensing, fluorescence assays have emerged as a rational option for highly sensitive and fast analyses. So far, many fluorescent probes including semiconductor quantum dots, fluorescent metal nanoclusters, and fluorescent metal organic frameworks have been developed for the fluorescence detection of $\mathrm{Fe}(\mathrm{III}) .{ }^{15-17}$ However, the preparation of these materials needs specialized synthetic skills and complicated purification procedures. Additionally, because of

${ }^{a}$ State Key Laboratory of Medicinal Chemical Biology, College of Pharmacy, Tianjin Key Laboratory of Molecular Drug Research, Nankai University, Tianjin 300353, China.E-mail: xirimo@nankai.edu.cn; yinyongmei@nankai.edu.cn

${ }^{b}$ Tianjin Medical University Eye Hospital, Tianjin 300384, China

$\uparrow$ Electronic supplementary information (ESI) available. See DOI: $10.1039 / \mathrm{c} 7 \mathrm{ra} 04122 \mathrm{e}$ the toxicity and water-insolubility, the application of these chemosensors has been greatly limited, especially in living cells.

As newcomers to the carbon nanomaterials family, carbon dots (CDs) have attracted tremendous attention owing to their captivating properties such as wavelength-tuneable emission, low cytotoxicity, excellent photostability, aqueous solubility, and favorable biocompatibility. ${ }^{18,19}$ As a consequence, CDs have been widely used in fluorescence sensing, bioimaging, drug delivery, etc. ${ }^{20-22}$ For chemical sensing applications, CDs-based $\mathrm{Fe}(\mathrm{III})$ sensors have been developed. ${ }^{23-30}$ For specifically sensing $\mathrm{Fe}$, the challenge is to avoid the interference from $\mathrm{Fe}(\mathrm{II})$. However, it is not so easy to set up a CDs-based sensing system to detect $\mathrm{Fe}(\mathrm{III})$ without interruptions from $\mathrm{Fe}(\mathrm{II}){ }^{23,25}$ Even if such sensor could be constructed with acceptable discrimination of $\mathrm{Fe}(\mathrm{III})$ and $\mathrm{Fe}(\mathrm{II})$, few could respond well to $\mathrm{Fe}(\mathrm{III})$ over a wide range of $\mathrm{pH}$ values. ${ }^{24}$

In this research, we prepared the CDs through a simple onepot hydrothermal method from used black tea, and the CDs can be efficiently quenched by Fe(III). The prepared CDs not only respond well to $\mathrm{Fe}(\mathrm{III})$ in a buffer over a range of $\mathrm{pH}$ from 4.5 to 9.0, but also sensitively respond to Fe(III) in water with negligible interference from $\mathrm{Fe}(\mathrm{II})$. Hence, a multianalyte sensing system was constructed to determine $\mathrm{Fe}(\mathrm{III}), \mathrm{H}_{2} \mathrm{O}_{2}$, and glucose, since $\mathrm{H}_{2} \mathrm{O}_{2}$ can oxidize $\mathrm{Fe}(\mathrm{II})$ to $\mathrm{Fe}(\mathrm{III})$ and glucose can be oxidized to yield $\mathrm{H}_{2} \mathrm{O}_{2}$ (Scheme 1). The sensing system was evaluated in human serum and living cells. 


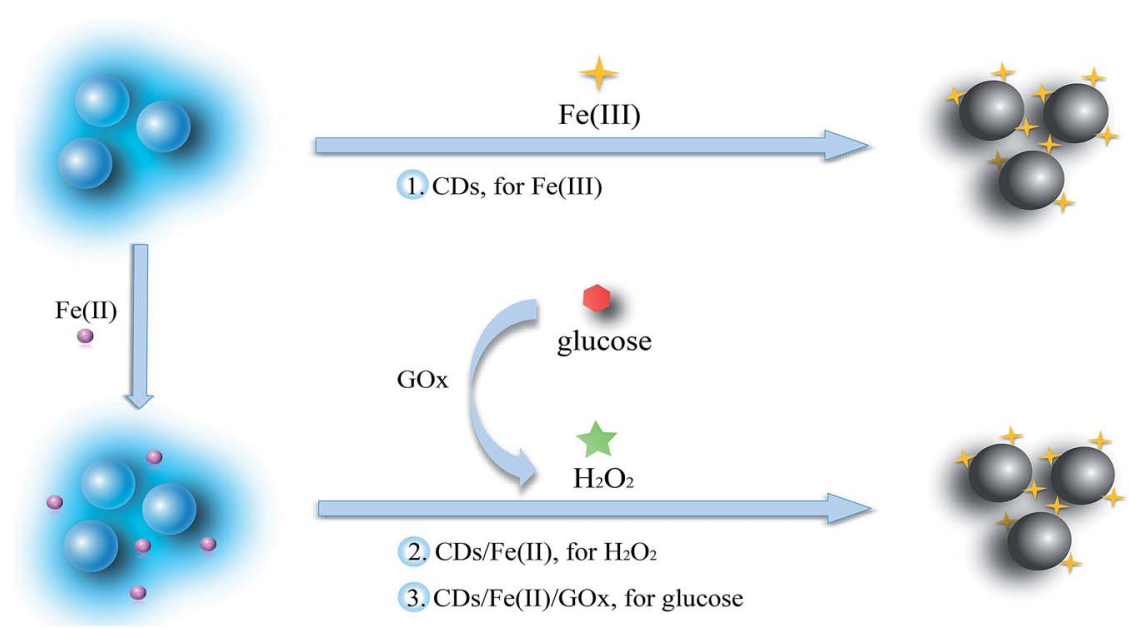

Scheme 1 A multianalyte fluorescent CDs-sensing system for sensing of $\mathrm{Fe}(\mathrm{III}), \mathrm{H}_{2} \mathrm{O}_{2}$, and glucose.

\section{Experimental section}

\section{Materials}

Jinjunmei black tea was bought from the local tea supermarket. $\mathrm{FeCl}_{3}, \mathrm{FeCl}_{2}, \mathrm{~Pb}\left(\mathrm{NO}_{3}\right)_{2}, \mathrm{ZnCl}_{2}, \mathrm{CuSO}_{4}, \mathrm{AlCl}_{3}, \mathrm{Hg}\left(\mathrm{NO}_{3}\right)_{2}, \mathrm{CdCl}_{2}$, $\mathrm{MgCl}_{2}, \mathrm{CaCl}_{2}, \mathrm{BaCl}_{2}, \mathrm{MnCl}_{2}, \mathrm{CoCl}_{2}, \mathrm{NiCl}_{2}, \mathrm{CrCl}_{3}, \mathrm{AgNO}_{3}$, glycine, cysteine, $\mathrm{H}_{2} \mathrm{O}_{2}$, glucose, and glucose oxidase were purchased from Aladdin Chemistry Co., Ltd. (Shanghai, China). Other chemicals were of analytical grade. Human serum was purchased from Beijing Solarbio Science \& Technology Co., Ltd. Purified water was prepared through a Millipore system and used throughout the experiment.

\section{Instruments}

UV-vis absorption spectra were recorded on a Shimadzu UV1750 spectrophotometer with one pair of $10 \mathrm{~mm}$ quartz cell. Fluorescence spectral recording and emission measurements were conducted on a Hitachi F-4600 FL spectrophotometer using $5 / 5 \mathrm{~nm}$ slit width and equipped with a $10 \mathrm{~mm}$ quartz cell. Fourier transform infrared spectra (FTIR) were acquired on a Bio-Rad FTS 6000 spectrometer using KBr pellets. The transmission electron microscopic (TEM) image was acquired on a FEI Tecnai G2 F20 microscopy operating at $200 \mathrm{kV}$. The particle size distribution was measured by using a Nicomp 380 submicron particle sizer. The X-ray photoelectron spectra (XPS) were carried out on an AXIS Ultra DLD X-ray photoelectron spectrometer. Fluorescence imaging experiments were performed on a Zeiss LSM710 confocal laser scanning microscope with an objective lens $(\times 40)$.

\section{Preparation of fluorescent CDs}

A hydrothermal method was used to prepare the CDs. Briefly, $1.8 \mathrm{~g}$ drying used black tea was added into $10 \mathrm{~mL}$ ultrapure water; then, the mixture was transferred into a $50 \mathrm{~mL}$ Teflonlined stainless steel autoclave. The mixture was heated at $200{ }^{\circ} \mathrm{C}$ for $5 \mathrm{~h}$ and then cooled to room temperature. The CDs solution was collected after removing the carbide slag through centrifugation at $12000 \mathrm{rpm}$ for $10 \mathrm{~min}$. The supernatant was purified by filtration through a $0.22 \mu \mathrm{m}$ filter membrane and then diluted with ultrapure water for further use.

\section{General procedure for fluorescence measurements}

Detection of $\mathbf{F e}(\mathrm{III})$. A series of $\mathrm{Fe}(\mathrm{III})$ solutions with concentrations of $0,5,10,20,30,40,50,80,100,200,400$, and $600 \mu \mathrm{M}$ were prepared in ultrapure water. Ten microliter of $\mathrm{Fe}(\mathrm{III})$ solution was added in the CDs solution $\left(990 \mu \mathrm{L}, 8 \mu \mathrm{g} \mathrm{mL} \mathrm{m}^{-1}\right)$, mixed, and incubated for $10 \mathrm{~min}$ at room temperature for recording the fluorescence emission spectra at $400 \mathrm{~nm}$.

The selectivity of CDs for sensing Fe(III) was evaluated by the interfered metal ions $\left(\mathrm{Fe}^{2+}, \mathrm{Cu}^{2+}, \mathrm{Cd}^{2+}, \mathrm{Cr}^{3+}, \mathrm{Zn}^{2+}, \mathrm{Mn}^{2+}, \mathrm{Ni}^{2+}\right.$, $\mathrm{Co}^{2+}, \mathrm{Al}^{3+}, \mathrm{Pb}^{2+}, \mathrm{Ag}^{+}, \mathrm{Hg}^{2+}, \mathrm{Mg}^{2+}, \mathrm{Ba}^{2+}, \mathrm{Ca}^{2+}, \mathrm{Na}^{+}$, and $\mathrm{K}^{+}$) under the same conditions. Besides, $100 \mu \mathrm{M}$ common anions and organic compounds $\left(\mathrm{PO}_{4}{ }^{3-}, \mathrm{SO}_{4}{ }^{2-}, \mathrm{CO}_{3}{ }^{2-}, \mathrm{Cl}^{-}\right.$, cysteine, dopamine, glycine, and ascorbic acid) were analyzed by the sensor with the same procedures as indicated above.

Additionally, the feasibility of the proposed method for the analysis of $\mathrm{Fe}(\mathrm{III})$ in human serum was investigated. After the samples of human serum were centrifuged at $10000 \mathrm{rpm}$ for $10 \mathrm{~min}$ and the precipitation was removed, the supernatant was kept for further use. Thus, different concentrations of $\mathrm{Fe}(\mathrm{III})$ ions $(10 \mu \mathrm{L})$ and supernatant $(10 \mu \mathrm{L})$ were added in the CDs solution $(980 \mu \mathrm{L})$. After incubation for $10 \mathrm{~min}$ at room temperature, the fluorescence emission spectra were recorded.

Detection of $\mathrm{H}_{2} \mathrm{O}_{2}$ and glucose. For $\mathrm{H}_{2} \mathrm{O}_{2}$ sensing, different concentrations of $\mathrm{H}_{2} \mathrm{O}_{2}(0,0.1,0.5,2.5,5,10,20,30,40,50,80$, and $100 \mu \mathrm{M}$ ) were added to the sensing system containing CDs (8 $\left.\mu \mathrm{g} \mathrm{mL}^{-1}\right)$ and $\mathrm{Fe}(\mathrm{II})(120 \mu \mathrm{M})$. The fluorescence emission spectra were recorded.

For the analysis of glucose, appropriate concentrations of GOx $\left(20 \mu \mathrm{g} \mathrm{mL}^{-1}\right)$ and $\mathrm{Fe}(\mathrm{II})(120 \mu \mathrm{M})$ were added into the CDs solution, followed by the addition of different concentrations of glucose $(0,0.1,0.5,2.5,5,10,20,30,40,50,80$, and $100 \mu \mathrm{M})$. The fluorescence emission spectra of the mixture were recorded after the reaction for $30 \mathrm{~min}$. For all the fluorescence 
measurements, the excitation wavelength was set at $320 \mathrm{~nm}$, and the emission was monitored at $400 \mathrm{~nm}$.

\section{Cytotoxicity investigation}

The cell viability was measured using the MTT assay. HeLa cells were propagated in Dulbecco's modified Eagle's medium (DMEM) supplemented with 10\% fetal bovine serum (FBS). Briefly, the cells were seeded into 96-well plates at a density of $8 \times 10^{3}$ cells in each well. After incubating for $24 \mathrm{~h}$ at $37^{\circ} \mathrm{C}$ in a $5 \% \mathrm{CO}_{2}$ humidified atmosphere, the cells were treated with various concentrations $(0,20,40,80,100,200,400$, and $800 \mu \mathrm{g}$ $\mathrm{mL}^{-1}$ ) of CDs solution and cultured for another $24 \mathrm{~h}$. At the end of the treatment, $20 \mu \mathrm{L}$ of MTT $\left(5 \mathrm{mg} \mathrm{mL}^{-1}\right)$ was added to each well, followed by additional incubation for $4 \mathrm{~h}$. The culture medium was then removed, and $150 \mu \mathrm{L}$ of DMSO was then added to dissolve the formazan crystals. The optical density (OD) of each well was measured at $570 \mathrm{~nm}$ with a microplate reader. The cell viability was estimated according to the following equation:

$$
\text { Cell viability }(\%)=\left(\mathrm{OD}_{\text {treated }} / \mathrm{OD}_{\text {control }}\right) \times 100 \%
$$

where $\mathrm{OD}_{\text {control }}$ was the $\mathrm{OD}$ in the absence of $\mathrm{CDs}$ and $\mathrm{OD}_{\text {treated }}$ was the OD in the presence of CDs.

\section{Fluorescence imaging of living cells}

HeLa cells were seeded in a glass-bottom cell culture dish at $37{ }^{\circ} \mathrm{C}$ in $5 \% \mathrm{CO}_{2}$ for $24 \mathrm{~h}$. The growth medium was removed and replaced by the culture medium containing CDs $\left(12 \mu \mathrm{g} \mathrm{mL}{ }^{-1}\right)$. After incubation for $24 \mathrm{~h}$, the cells were washed for three times with PBS. For monitoring endogenous $\mathrm{H}_{2} \mathrm{O}_{2}$, cells were pretreated with $1 \mu \mathrm{g} \mathrm{mL}^{-1}$ phorbol myristate acetate (PMA) or $1 \mathrm{mM} \mathrm{N}$-acetylcysteine (NAC) for $1 \mathrm{~h}$. Similarly, for imaging of exogenous $\mathrm{H}_{2} \mathrm{O}_{2}$, cells were treated with $100 \mu \mathrm{M} \mathrm{H}_{2} \mathrm{O}_{2}$ for $1 \mathrm{~h}$. After incubation, cells were washed thoroughly three times and kept in PBS for the fluorescence imaging. Thereafter, $200 \mu \mathrm{M}$ $\mathrm{Fe}(\mathrm{III})$ or $120 \mu \mathrm{M}$ Fe(II) was added and incubated for $30 \mathrm{~min}$. The fluorescence signal was recorded with the excitation of $405 \mathrm{~nm}$.

\section{Results and discussion}

\section{Characterization of CDs}

The CDs were prepared by a simple one-pot hydrothermal method from used black tea. Fig. 1 shows the representative TEM image and size distribution histogram of the products, revealing that the average size of the monodispersed nanoparticles was around $4.6 \mathrm{~nm}$. FTIR spectrum was obtained to identify the surface functional groups presented on the asprepared CDs. As shown in Fig. S1, $\uparrow$ the characteristic absorption band at $3286 \mathrm{~cm}^{-1}$ was assigned to the stretching vibration of $\mathrm{O}-\mathrm{H}$ and $\mathrm{N}-\mathrm{H}$, while $\mathrm{C}-\mathrm{H}$ stretching vibration was observed at $2962 \mathrm{~cm}^{-1}$. The peaks at 1666 and $1450 \mathrm{~cm}^{-1}$ could be identified as the asymmetric and symmetric vibrations of $\mathrm{COO}^{-}$, respectively. ${ }^{31}$ The absorption band of $-\mathrm{NH}_{2}$ stretching vibrations at $1543 \mathrm{~cm}^{-1}$ was also observed, and the bands in the range of 1083-1323 $\mathrm{cm}^{-1}$ were attributed to the large amount of C-O groups. ${ }^{32}$

The surface composition and elemental analysis for the resultant nanoparticles were characterized by XPS. The XPS survey spectrum (Fig. 2A) revealed that the CDs were mainly composed of carbon $(68.68 \%)$, oxygen $(23.42 \%)$, and nitrogen (7.9\%). The high-resolution XPS spectrum of C 1s (Fig. 2B) showed three peaks at $284.6,286.0$, and $287.8 \mathrm{eV}$, which were assigned to $\mathrm{C}-\mathrm{C}, \mathrm{C}-\mathrm{N} / \mathrm{C}-\mathrm{O}$, and $\mathrm{C}=\mathrm{O}$, respectively. ${ }^{33}$ The two peaks at 531.3 and $532.1 \mathrm{eV}$ in the $\mathrm{O}$ 1s spectrum (Fig. 2C) were associated with the $\mathrm{C}=\mathrm{O}$ and $\mathrm{C}-\mathrm{OH} / \mathrm{C}-\mathrm{O}-\mathrm{C}$ bands, respectively. Additionally, the $\mathrm{N}$ 1s spectrum (Fig. 2D) showed two peaks at 399.7 and $401.4 \mathrm{eV}$, which were attributed to $\mathrm{C}-\mathrm{N}-\mathrm{C}$ and $\mathrm{N}-\mathrm{H}$, respectively. ${ }^{34}$ The surface components of the resultant CDs determined by XPS were consistent with the FTIR results. These data demonstrated that the as-prepared CDs function with hydroxyl and carboxylic/carbonyl moieties that may originate from the carbohydrates in black tea.

\section{Optical properties of CDs}

The remarkable optical properties of the synthesized CDs were confirmed by the UV-vis absorption and fluorescence spectra of the aqueous dispersion of the nanoparticles. As illustrated in Fig. 3, the UV-vis spectrum shows two absorption peaks at $270 \mathrm{~nm}$ and $320 \mathrm{~nm}$, which were attributed to the $\pi-\pi^{*}$ transition of $\mathrm{C}=\mathrm{C}$ bonds and $\mathrm{n}-\pi^{*}$ transition of $\mathrm{C}=\mathrm{O}$ bonds in CDs, respectively. ${ }^{25,35}$ The emission spectra showed a strong emission with the maximum emission wavelength at $400 \mathrm{~nm}$ under excitation at $320 \mathrm{~nm}$. A bright blue luminescence of CDs was observed under UV light (365 nm) (Fig. 3, inset), revealing their blue photoluminescence property. Additionally, with an increase in excitation wavelength from $290 \mathrm{~nm}$ to $420 \mathrm{~nm}$, the maximum emission shifted from $398 \mathrm{~nm}$ to $490 \mathrm{~nm}$ along with variation in the emission intensity (Fig. S2†). The strongest emission spectrum was observed at the excitation wavelength of $320 \mathrm{~nm}$. The excitation-dependent fluorescence behavior of CDs resulted from the different sizes and surface states of nanoparticles, ${ }^{36}$ as in the case of most of the luminescent CDs and graphene quantum dots. ${ }^{37-39}$

\section{Stability of CDs}

To investigate the stability of CDs, fluorescence intensity toward various $\mathrm{pH}$ values, high ionic strength, and continuous UV irradiation were measured. Fig. S3A $\dagger$ presents the emission spectrum of CDs at different $\mathrm{pH}$ values. Evidently, CDs exhibited strong and stable fluorescence in the range of $\mathrm{pH}$ from 4.5 to 9. The stable fluorescence intensities could be understood in terms of the change in surface charge owing to protonationdeprotonation. $^{36}$ As shown in Fig. S3B, $\uparrow$ the fluorescence intensity changed slightly with varying $\mathrm{NaCl}$ concentrations, which resulted from no ionization of groups located on the CDs surface. ${ }^{40}$ Moreover, the fluorescence intensity did not significantly change after continuous Xe lamp (365 nm) irradiation for 60 min (Fig. S3C $\dagger$ ), demonstrating excellent photostability of the CDs. Considering the results above, it was confirmed that the CDs were highly stable under different conditions. 

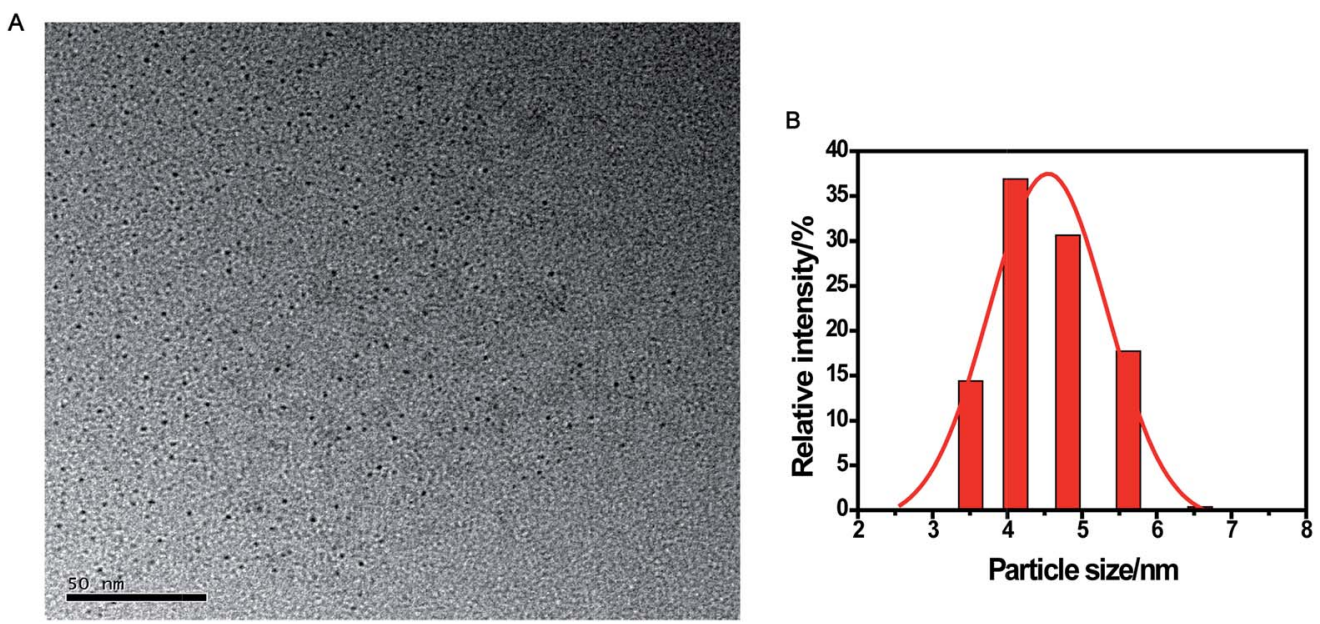

Fig. 1 TEM image (A) and the corresponding size distribution histograms (B) of the CDs.
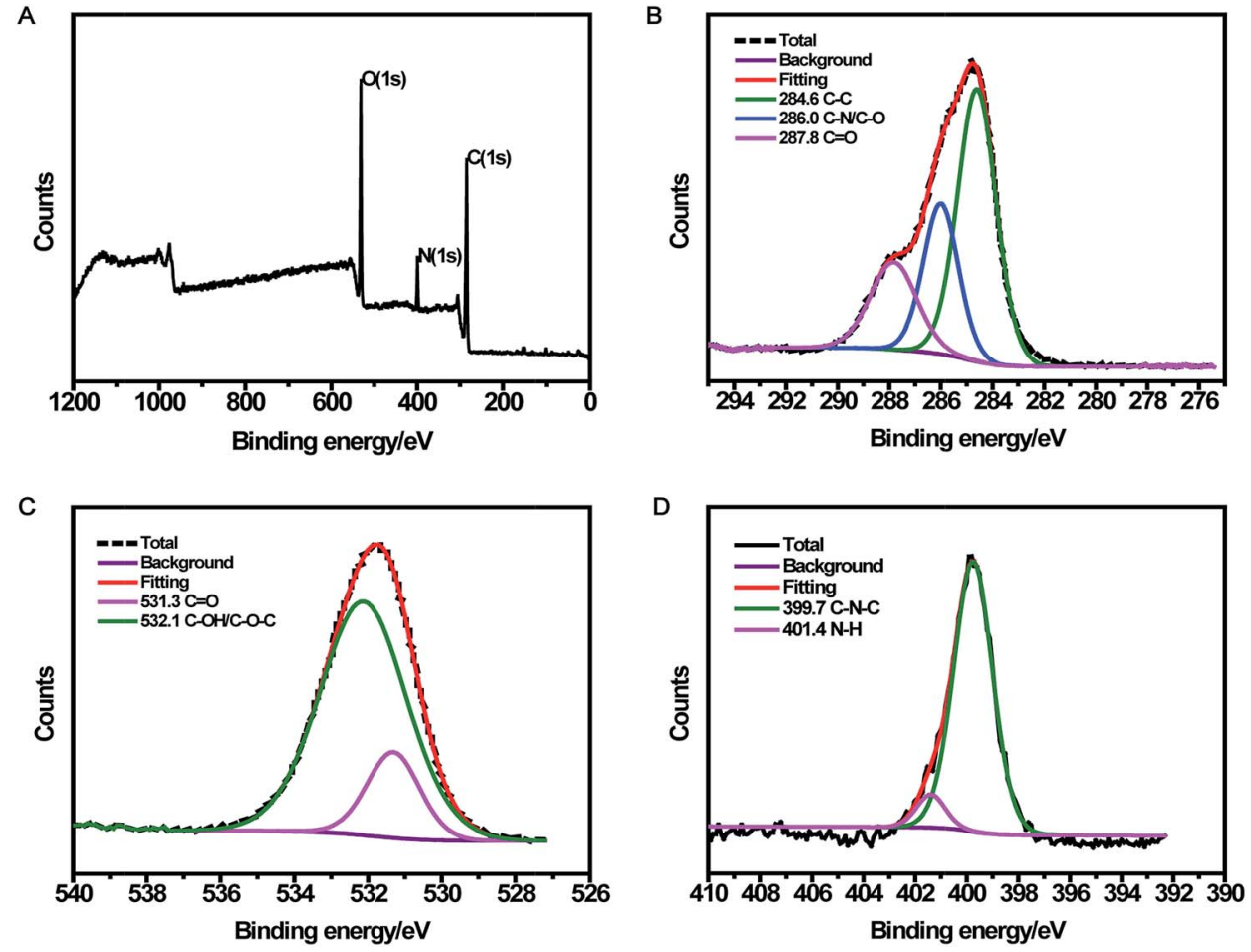

Fig. 2 Survey (A) and high-resolution C 1s (B), O 1s (C), and N 1s (D) XPS spectra of CDs.

\section{Fluorescence response of CDs toward $\mathrm{Fe}(\mathrm{III})$}

As displayed in Fig. 4, the CDs showed strong fluorescence with the excitation wavelength of $320 \mathrm{~nm}$ and the fluorescence was quenched dramatically upon the addition of $100 \mu \mathrm{M} \mathrm{Fe}(\mathrm{III})$. According to the XPS data, oxygen was the main component of $\mathrm{CDs}$, and the $-\mathrm{OH} /-\mathrm{O}-\mathrm{C}$ groups make up about $81 \%$ of the entire oxygen-containing groups. Meanwhile, the FTIR results demonstrated that plentiful hydroxyl groups exist on the surface of the CDs. Furthermore, the electronegativity of oxygencontaining groups was higher than that of nitrogencontaining groups. ${ }^{41}$ Thus, we suggested that the quenching of fluorescence was mostly attributed to the binding affinity of hydroxyl groups on the surface of CDs to $\mathrm{Fe}(\mathrm{III})$. Fe(III) could react with the hydroxyl groups of CDs to form the complex by a special coordination interaction. In order to further explore the mechanism of fluorescence quenching by $\mathrm{Fe}(\mathrm{III})$, fluorescence decay curves of CDs in the absence and presence of $\mathrm{Fe}$ (III) were examined. As displayed in Fig. $\mathrm{S} 4, \uparrow$ two fluorescence decay curves were completely overlapped and had no significant change. Moreover, the average fluorescence lifetime was calculated to be $5.53 \mathrm{~ns}$ for CDs and $5.50 \mathrm{~ns}$ for CDs-Fe(III) complex. This is because static quenching arising from the formation of 


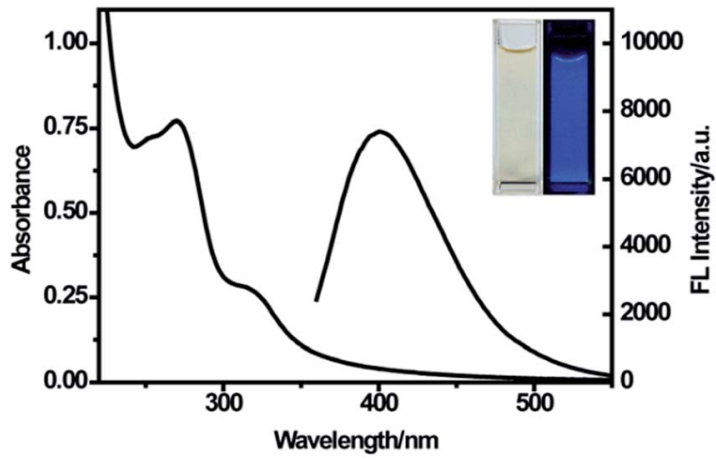

Fig. 3 UV-vis absorption spectra and emission spectra of CDs at the excitation of $320 \mathrm{~nm}$. Inset: photographs of CDs under visible light (left) and a UV beam of $365 \mathrm{~nm}$ (right).

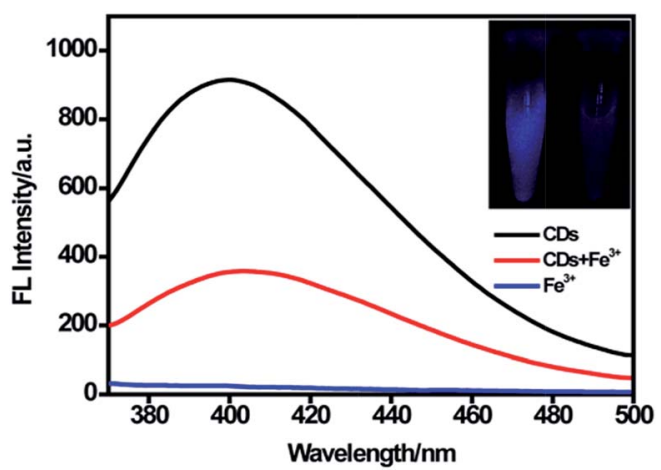

Fig. 4 Fluorescence spectra of CDs in the absence and presence of $100 \mu \mathrm{M} \mathrm{Fe}(\mathrm{III})$ at the excitation of $320 \mathrm{~nm}$. Insets showed the photographs of the CDs solutions in the absence and presence of Fe(III) under UV light (365 $\mathrm{nm}$ ).

a ground-state complex between the fluorescence material and quencher could not lead to the change of lifetime. However, dynamic quenching could result in a decrease of lifetime. ${ }^{\mathbf{2 0 , 4 2 , 4 3}}$ Our result showed no significant change in the lifetime, indicating the occurrence of static quenching and the formation of a complex.

\section{Fluorescence sensing for $\mathrm{Fe}(\mathrm{III})$}

For better performance in sensing Fe(III), the effects of reaction time and medium were evaluated. Fig. S5A $\dagger$ shows the fluorescence response of CDs after adding different concentrations of $\mathrm{Fe}(\mathrm{III})(10 \mu \mathrm{M}$ and $100 \mu \mathrm{M})$. It was found that the fluorescence response became stable in $10 \mathrm{~min}$. In addition, the fluorescence response toward $\mathrm{Fe}(\mathrm{III})$ in ultrapure water and buffer with different $\mathrm{pH}$ values is shown in Fig. S5B. $\dagger$ The results indicated that CDs could respond well to $\mathrm{Fe}(\mathrm{III})$ in ultrapure water and buffer over the range of $\mathrm{pH}$ from 4.5 to 9.0. The wide $\mathrm{pH}$ range for sensing $\mathrm{Fe}(\mathrm{III})$ could promote the application of CDs at various $\mathrm{pH}$ conditions, especially in cells. Some studies did not investigate the $\mathrm{pH}$ range for sensing $\mathrm{Fe}(\mathrm{III})$. Shi and co-workers developed the CDs-based sensor for $\mathrm{Fe}(\mathrm{III})$ over the range of $\mathrm{pH}$ in $6.0-8.0 .^{23}$ Sachdev et al. ${ }^{25}$ did obtain a wide $\mathrm{pH}$ range; however, the results of linear range with $0-6 \mu \mathrm{M}$ and $F / F_{0}$ value of 0.8 for $\mathrm{Fe}(\mathrm{II})$ were not satisfactory $\left(F_{0}\right.$ and $F$ are fluorescence intensities at $400 \mathrm{~nm}$ in the absence and presence of ions, respectively).

Fig. S6† presented a gradual decrease in the fluorescence intensity with increasing $\mathrm{Fe}(\mathrm{III})$ concentration, revealing a response of CDs to $\mathrm{Fe}(\mathrm{III})$. In the presence of $600 \mu \mathrm{M} \mathrm{Fe}(\mathrm{III})$, the quenching efficiency could reach up to $89 \%$ (Fig. 5A). $\left(F_{0} / F\right)$ showed a perfect linear relationship $\left(R_{2}=0.999\right) v s$. the concentration of $\mathrm{Fe}(\mathrm{III})$ in the range of $0.25-60 \mu \mathrm{M}$ (Fig. $5 \mathrm{~B}$ ). Likewise, the limit of detection (LOD) of Fe(III) was estimated to be $0.25 \mu \mathrm{M}$ (according to a signal-to-noise ratio of 3 ), which was comparable to those detection limits obtained by other fluorescent probes for $\mathrm{Fe}(\mathrm{III})$ in Table $1 .^{25,44-47}$

Selectivity is another important parameter to evaluate the performance of the sensing system. Therefore, the fluorescence intensity of CDs in the presence of different metals ions was monitored (Fig. 6). A much lower fluorescence intensity was observed for CDs upon the addition of Fe(III). However, the fluorescence intensity did not tremendously decrease after adding $\mathrm{Fe}(\mathrm{II})$ into the CDs dispersion with a $F / F_{0}$ value of 0.96 , which is larger than those of carbon nanomaterials reported in the literature. For example, Sachdev et al. ${ }^{25}$ reported a $F / F_{0}$ value of 0.8 for $\mathrm{Fe}(\mathrm{II})$ using CDs from coriander leaves. Zhang et al. ${ }^{\mathbf{4 4}}$ and Chen et $a l .{ }^{48}$ reported $F / F_{0}$ values of 0.45 and 0.89 , respectively. Although a negligible interference from $\mathrm{Fe}(\mathrm{II})$ to the CDs in sensing Fe(III) was observed, the efficiency of Fe(III) sensing greatly relied on the $\mathrm{pH}$ of the sample solution. ${ }^{24}$ The prepared CDs in our study showed more specific recognition of $\mathrm{Fe}(\mathrm{III})$ from $\mathrm{Fe}$ (II) and responded well to $\mathrm{Fe}$ (III) in a wide range of $\mathrm{pH}$ (4.5 to 9.0), indicating the satisfactory tolerance of this sensing system. The discrimination effect for Fe(III) ions might originate from the exceptional coordination between $\mathrm{Fe}$ (III) ions and hydroxyl groups of CDs. ${ }^{46}$ Besides metal ions, various anions and organic molecules that may co-exist with $\mathrm{Fe}(\mathrm{III})$ were observed under the same conditions. As shown in Fig. S7, $\dagger$ in the presence of these interfering species, the fluorescence intensity had no significant change. The results confirmed the good selectivity of the proposed method for Fe(III) sensing.

\section{Multianalyte sensing system for $\mathrm{H}_{2} \mathrm{O}_{2}$ and glucose}

A multianalyte fluorescent CDs sensing platform was designed for the qualitative and quantitative analysis of $\mathrm{H}_{2} \mathrm{O}_{2}$ and glucose, which depended on the stoichiometric relationship in the biochemical reaction.

In the presence of $\mathrm{H}_{2} \mathrm{O}_{2}$ (Fig. 7A), Fe(II) was oxidized into $\mathrm{Fe}(\mathrm{III})$, resulting in the fluorescence quenching of CDs. To demonstrate the feasibility of the multianalyte sensing system for $\mathrm{H}_{2} \mathrm{O}_{2}$ detection, we evaluated the quenching phenomena of CDs caused by $\mathrm{H}_{2} \mathrm{O}_{2}$ (Fig. S8 $\dagger$ ). In order to establish the assay for detecting $\mathrm{H}_{2} \mathrm{O}_{2}$, the reaction time and concentration of $\mathrm{Fe}(\mathrm{II})$ for sensing $\mathrm{H}_{2} \mathrm{O}_{2}$ were optimized. As illustrated in Fig. S9A, $\uparrow$ the relative fluorescence intensities had no obvious change when the concentration of $\mathrm{Fe}(\mathrm{II})$ was higher than $120 \mu \mathrm{M}$. The fluorescence was gradually stable within $10 \mathrm{~min}$, showing that the reaction was complete (Fig. S9B $\dagger$ ). Thus, $120 \mu \mathrm{M}$ Fe(II) and 

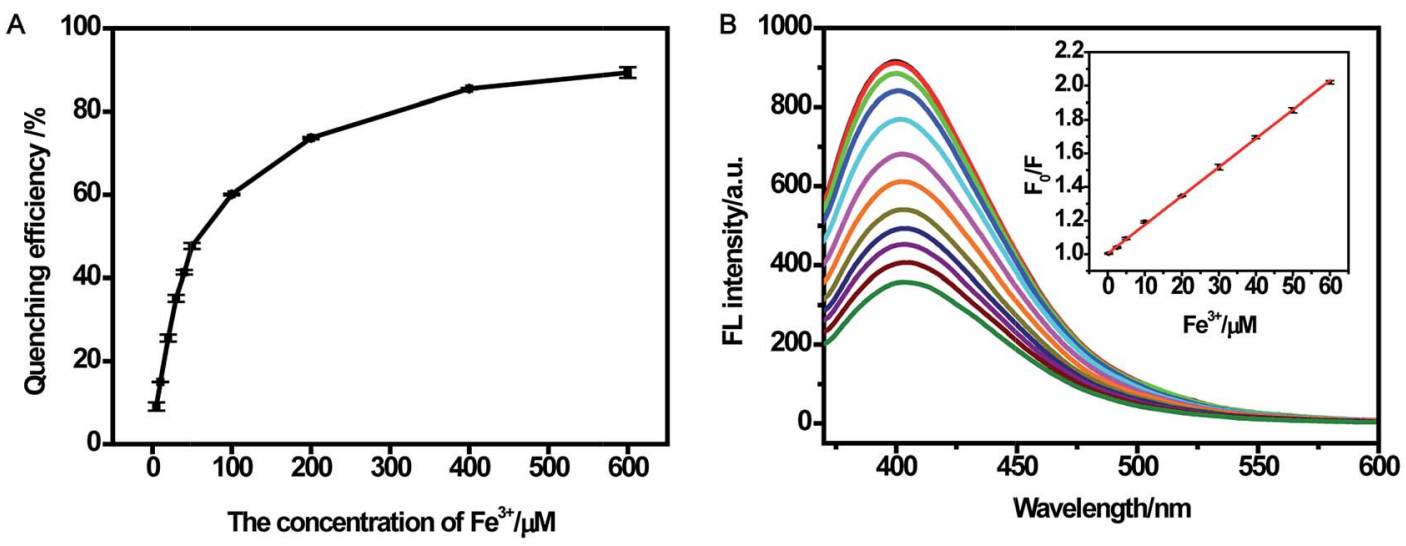

Fig. 5 (A) The variation of the quenching efficiency of CDs in the presence of different concentrations of Fe(II) from 0 to $600 \mu M$. (B) Fluorescence emission spectra of CDs upon addition of various concentrations of Fe(III) (from top to bottom: 0, 0.25, 2.5, 5, 10, 20, 30, 40, 50, 60, 80, and $100 \mu \mathrm{M})$. Inset is the linear calibration plot for $F_{0} / F$ versus different concentrations of Fe(III) from $0.25 \mu \mathrm{M}$ to $60 \mu \mathrm{M}$.

10 min incubation time were chosen for the quantitative determination of $\mathrm{H}_{2} \mathrm{O}_{2}$. Under the optimum experimental conditions, the sensitivity, linear response range, and detection limit of the multianalyte sensing system for $\mathrm{H}_{2} \mathrm{O}_{2}$ were measured. $\left(F_{0}-F\right) / F_{0} v s$. concentration of $\mathrm{H}_{2} \mathrm{O}_{2}$ from 0.1 to 100 $\mu \mathrm{M}$ was observed (Fig. S10†). As shown in Fig. 7B, there was a good linear correlation between $\left(F_{0}-F\right) / F_{0}$ and the concentration of $\mathrm{H}_{2} \mathrm{O}_{2}$ in the range from $0.1 \mu \mathrm{M}$ to $40 \mu \mathrm{M}$, providing a detection limit of $0.82 \mu \mathrm{M}$.

As illustrated in Fig. 7C, $\mathrm{H}_{2} \mathrm{O}_{2}$ was produced in the oxidization reaction of glucose in the presence of GOx. Under the existence of the $\mathrm{H}_{2} \mathrm{O}_{2}, \mathrm{Fe}$ (II) was oxidized to $\mathrm{Fe}$ (III), and $\mathrm{Fe}$ (III) could yield the fluorescence quenching of CDs. Based on this consideration, indirect detection of glucose can be performed. A comparison of the relative fluorescence intensity changes of CDs after the addition of glucose, GOx, and "glucose + GOx + $\mathrm{Fe}(\mathrm{II})$ " is shown in Fig. S11, $\dagger$ suggesting the feasibility of the multianalyte sensing system for sensing glucose. Then, the concentration of GOx and reaction time were optimized. When the concentration of GOx was higher than $20 \mu \mathrm{g} \mathrm{mL} \mathrm{m}^{-1}$, the fluorescence intensity had no significant change (Fig. S12A $\dagger$ ). Fig. $\mathrm{S} 12 \mathrm{~B} \uparrow$ shows that the reaction was complete within $30 \mathrm{~min}$. Thus, $20 \mu \mathrm{g} \mathrm{mL} \mathrm{m}^{-1} \mathrm{GOx}$ and $30 \mathrm{~min}$ incubation time were chosen as the optimal conditions for glucose assay. Then, the sensitive determination of glucose was performed by adding different concentrations of glucose into the sensing system of CDs, $\mathrm{Fe}(\mathrm{II})$, and GOx under the optimum experimental conditions

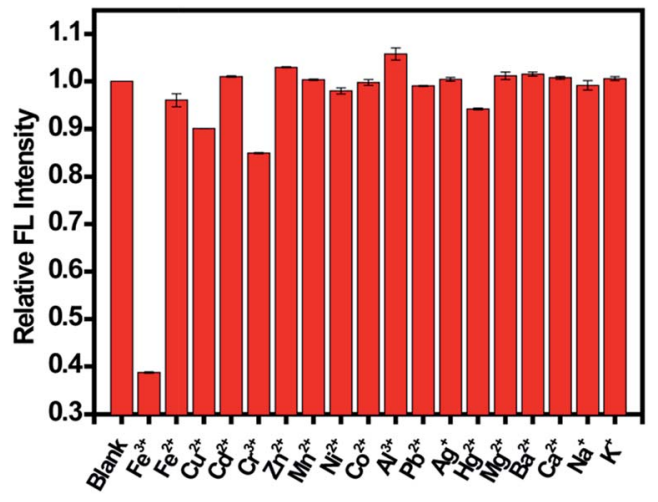

Fig. 6 Fluorescence response of CDs in the presence of different metal ions. The concentration of metal ions was $100 \mu \mathrm{M}$.

(Fig. S13†). The $\left(F_{0}-F\right) / F_{0}$ value indicated that the linear relationship was good in relation to glucose concentration ranging from $0.1 \mu \mathrm{M}$ to $50 \mu \mathrm{M}$ (Fig. 7D). The detection limit was estimated to be $1.71 \mu \mathrm{M}$. This demonstrated the sensing system could be used for glucose detection with satisfactory sensitivity.

\section{Intracellular imaging of $\mathrm{Fe}(\mathrm{III})$ and $\mathrm{H}_{2} \mathrm{O}_{2}$}

For further biological applications, MTT assays were performed to evaluate the cytotoxicity of the CDs using cervical cancer HeLa cells. As expected, Fig. S14† showed that the cell viability was estimated to be greater than $90 \%$ upon the addition of CDs

Table 1 Comparison of different fluorescent sensors for Fe(III)

\begin{tabular}{llll}
\hline Fluorescence probes & Carbon source & $\begin{array}{l}\text { Detection limit } \\
(\mu \mathrm{M})\end{array}$ & $\begin{array}{l}\text { Linear range } \\
(\mu \mathrm{M})\end{array}$ \\
\hline Graphene quantum dots & Aspartic acid & 0.26 & $0-50$ \\
Carbon dots & DL-Malic acid & 0.8 & $0-200$ \\
Carbon dots & Chitosan, acetic acid and ethylenediamine & 5.3 & $0.17-32$ \\
Carbon dots & Citric acid and tris & 1.3 & $2-50$ \\
Carbon dots & Coriander leaves & 0.4 & 45 \\
Multianalyte sensing system & Used black tea & 0.25 & $0-6$ \\
\end{tabular}


A
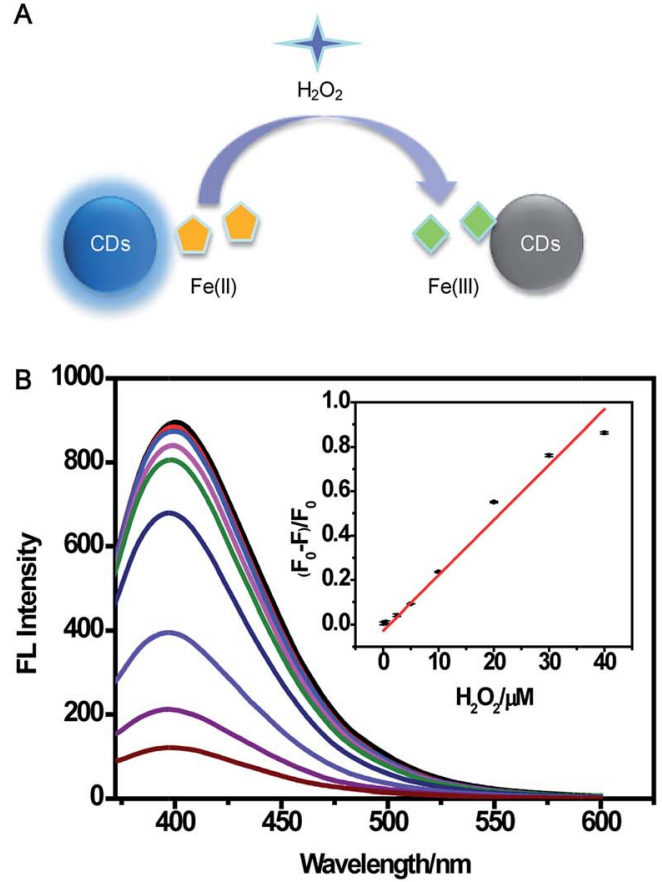

C

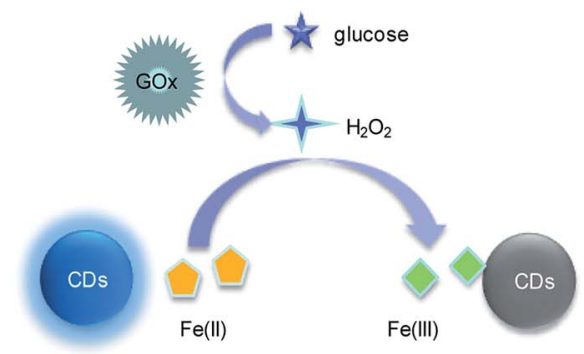

D

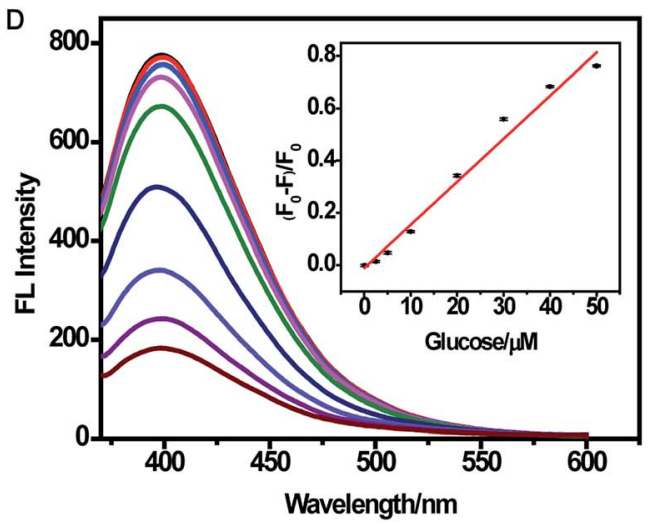

Fig. 7 Schematic illustration of $\mathrm{H}_{2} \mathrm{O}_{2}(A)$ and glucose (C) detection mechanism using CDs. (B) Fluorescence emission spectra for the determination of $\mathrm{H}_{2} \mathrm{O}_{2}(0.1-40 \mu M)$. Inset: $\left(F_{0}-F\right) / F_{0}$ vs. $\left[\mathrm{H}_{2} \mathrm{O}_{2}\right]$. (D) Fluorescence emission spectra for the determination of glucose $(0.1-50 \mu M)$. Inset: $\left(F_{0}-F\right) / F_{0}$ vs. [glucose].

over a wide concentration range of 20 to $800 \mu \mathrm{g} \mathrm{mL}{ }^{-1}$. High cell viability confirmed the low cytotoxicity and excellent biocompatibility of the as-prepared CDs, which indicated the great potential of CDs for monitoring $\mathrm{Fe}(\mathrm{III})$ and $\mathrm{H}_{2} \mathrm{O}_{2}$ in living cells.

Taken together, the CDs gave advantages of small size, high selectivity, good photostability, and, especially, biocompatibility, substantially making them superior in potential bioimaging applications. Accordingly, confocal fluorescence images were obtained to further demonstrate the availability of CDs in intracellular $\mathrm{Fe}(\mathrm{III})$ and $\mathrm{H}_{2} \mathrm{O}_{2}$ imaging for HeLa cells. As illustrated in Fig. 8A, the fluorescence can be observed in the CDsloaded cell membrane and the cytoplasmic area, while the fluorescence signal was quite weak in the cell nucleus. The fluorescence intensity decreased distinctly upon the addition of $200 \mu \mathrm{M}$ $\mathrm{Fe}(\mathrm{III})$ and incubation of $30 \mathrm{~min}$ at room temperature, and the quenching efficiency was calculated to be about $74 \%$. Furthermore, the bright-field measurements indicated that the cells are viable throughout the imaging experiments. All the observations indicated that the proposed multianalyte CDs could be applied for the effective semi-quantitative imaging of $\mathrm{Fe}(\mathrm{III})$ in living cells. Further, the sensing system for monitoring $\mathrm{H}_{2} \mathrm{O}_{2}$ in living biological systems was conducted. Fig. 8B shows that HeLa cells loaded with $12 \mu \mathrm{g} \mathrm{mL}{ }^{-1}$ CDs showed bright fluorescence. The treatment of CDs-loaded cells with $100 \mu \mathrm{M} \mathrm{H} \mathrm{H}_{2} \mathrm{O}_{2}$ for $60 \mathrm{~min}$ caused no change in the fluorescence intensity. A striking fluorescence decrease was observed upon the addition of $120 \mu \mathrm{M}$ $\mathrm{Fe}(\mathrm{II})$ into the growth medium and incubation of $30 \mathrm{~min}$.

To prove further that the generation of fluorescence signal was dependent on $\mathrm{H}_{2} \mathrm{O}_{2}$, PMA that can induce $\mathrm{H}_{2} \mathrm{O}_{2}$ generation $^{49}$ and NAC that can scavenge free-radicals in cancer cells ${ }^{50}$ were used as the modulators of intracellular $\mathrm{H}_{2} \mathrm{O}_{2}$ levels. PMA $\left(1 \mu \mathrm{g} \mathrm{mL}{ }^{-1}\right)$ or NAC $(1 \mathrm{mM})$ was added to test the ability of the sensing system to monitor the endogenous bursts of $\mathrm{H}_{2} \mathrm{O}_{2}$ produced within living cells. After the addition of $\mathrm{Fe}(\mathrm{II})$, the fluorescence intensity in the PMA-treated cells in Fig. 8C was significantly decreased, similar to that of $\mathrm{H}_{2} \mathrm{O}_{2}$-treated cells, while the fluorescence intensity in the NAC-treated cells had a negligible change (Fig. 8D).

In addition, we investigated the effect of the native $\mathrm{H}_{2} \mathrm{O}_{2}$ level of tumor cells on fluorescence imaging. The CDs-loaded cells were incubated with $\mathrm{Fe}(\mathrm{II})$ for $30 \mathrm{~min}$; then, the fluorescence signals within the cells were analyzed. As shown in Fig. 8E, a decrease in fluorescence intensity was observed, which could be attributed to the $\mathrm{H}_{2} \mathrm{O}_{2}$ existing in the tumor cells. $^{51}$ Consequently, all the results demonstrated that the multianalyte CDs sensing system has good potential for the imaging of intracellular $\mathrm{H}_{2} \mathrm{O}_{2}$.

\section{Detection of $\mathrm{Fe}(\mathrm{III})$ and glucose in human serum samples}

In order to evaluate the efficiency of the multianalyte sensing system in detecting $\mathrm{Fe}$ (III) or glucose, human serum samples were selected. Human serum samples were spiked with different concentrations of $\mathrm{Fe}(\mathrm{III}) /$ glucose and measured with the proposed methods: high analytical precision and good recoveries were obtained (Table $\mathrm{S} 1 \dagger$ ). These results further justified the reliability and feasibility of the multianalyte sensing system for monitoring $\mathrm{Fe}(\mathrm{III})$ or glucose in biological samples. 
Bright field

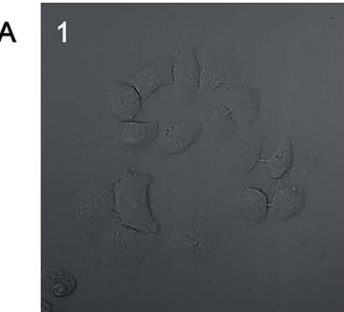

B

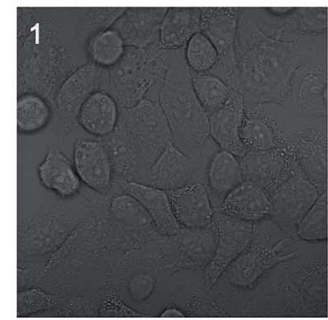

C

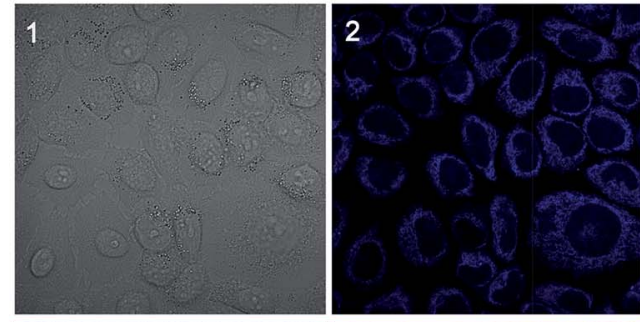

D

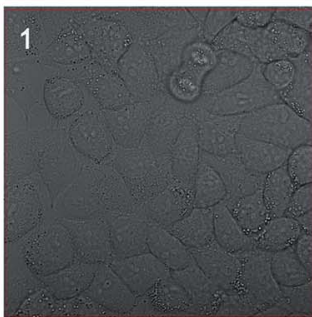

E

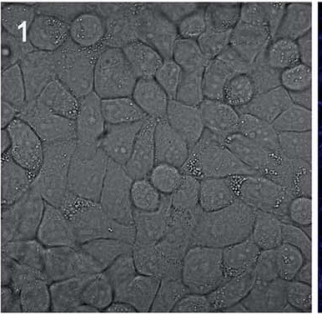

Fluorescence
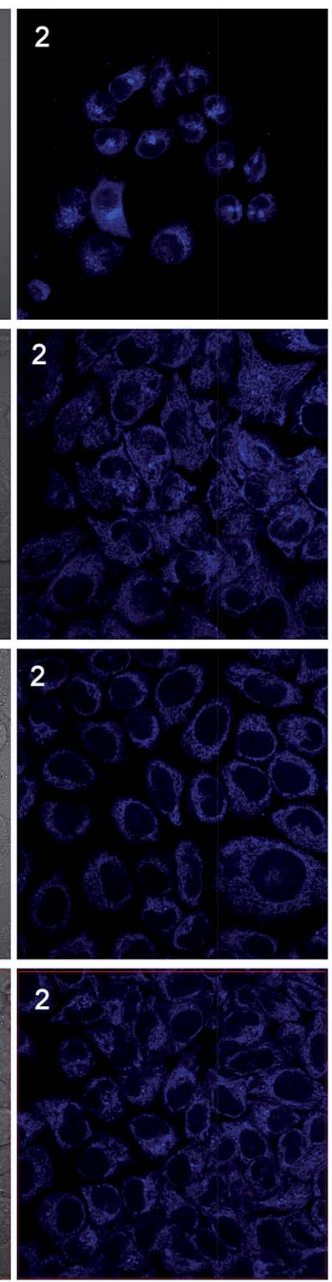

2

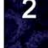

2

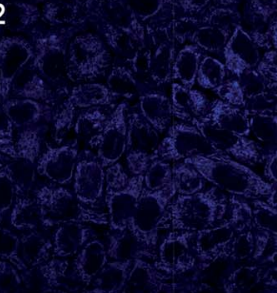

Fluorescence
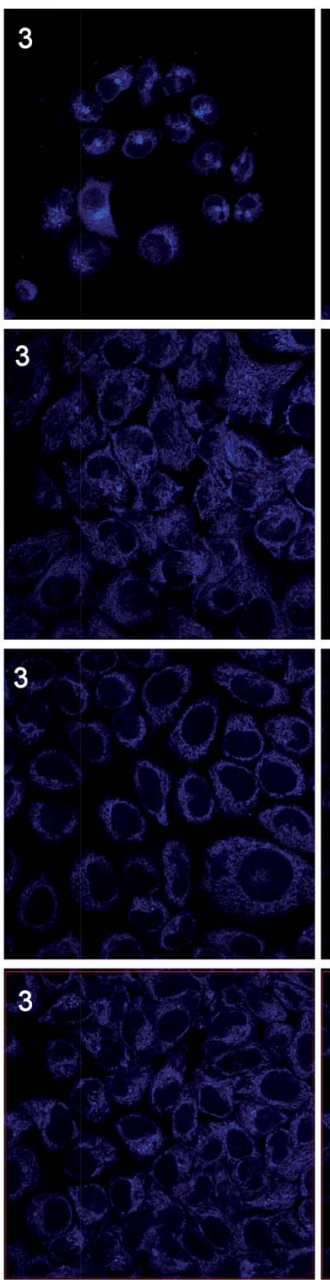

3

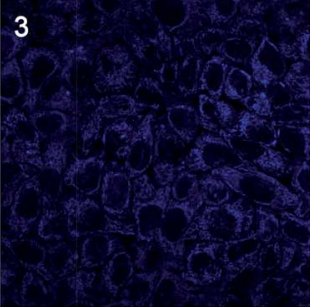

Fluorescence
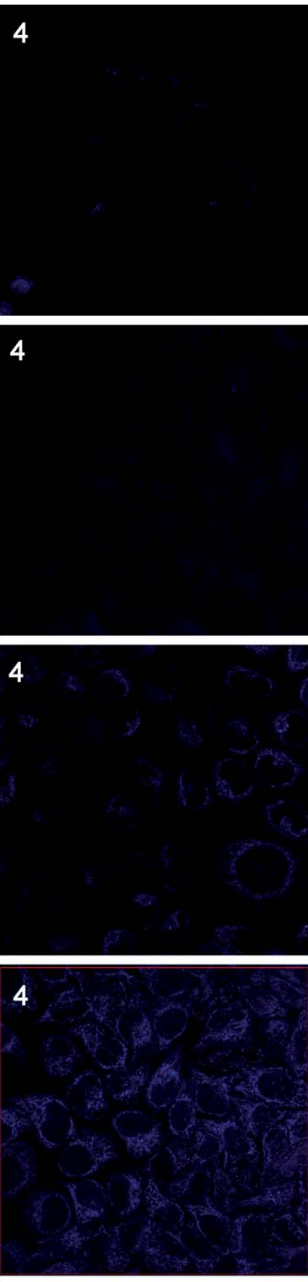

4

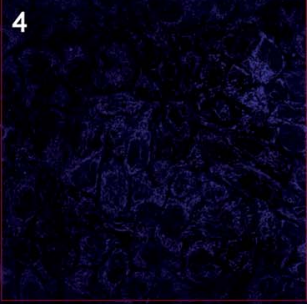

FL intensity integrated histogram
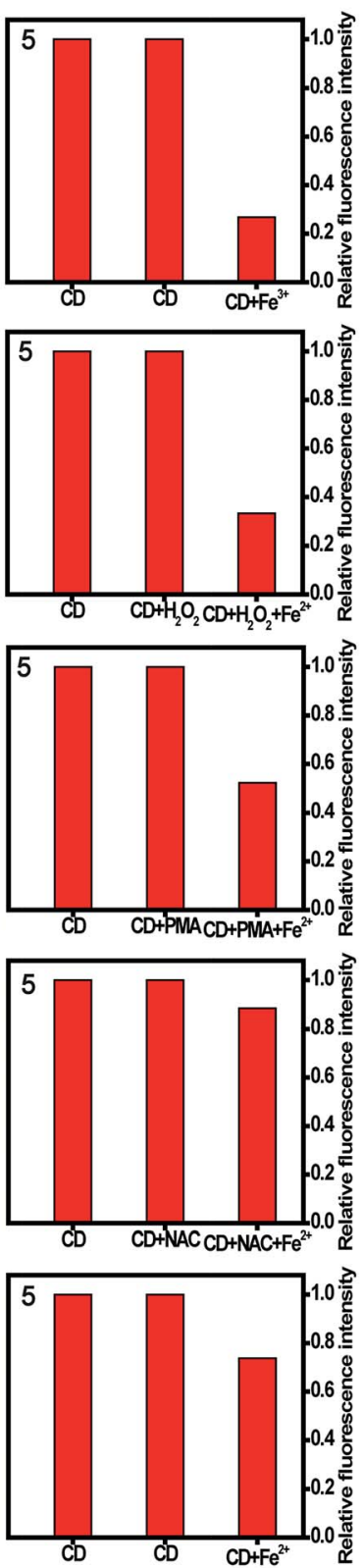

Fig. 8 Confocal fluorescence images of living HeLa cells labeled with CDs (12 $\left.\mu \mathrm{g} \mathrm{mL}^{-1}\right)$ under different conditions. Bright-field image (1, A-E) and fluorescence image (2, A-E) of HeLa cells labeled with CDs. (A) Representative images of HeLa cells treated with CDs and Fe(III): (A3) only

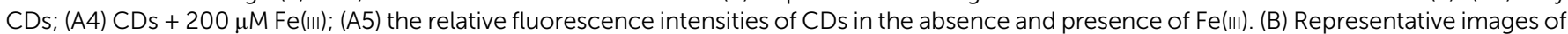
HeLa cells treated with CDs, $\mathrm{H}_{2} \mathrm{O}_{2}$, and Fe(॥): (B3) CDs $+100 \mu \mathrm{M} \mathrm{H}_{2} \mathrm{O}_{2}$; (B4) CDs + $100 \mu \mathrm{M} \mathrm{H}_{2} \mathrm{O}_{2}+120 \mu \mathrm{M}$ Fe(॥); (B5) the relative fluorescence intensities of $\mathrm{CDs}$ in the absence and presence of $\mathrm{H}_{2} \mathrm{O}_{2}$ and $\mathrm{Fe}(॥)$. (C) Representative images of HeLa cells treated with CDs, PMA, and Fe(॥): (C3) $\mathrm{CDs}+1 \mu \mathrm{g} \mathrm{mL}{ }^{-1} \mathrm{PMA}$; (C4) CDs $+1 \mu \mathrm{g} \mathrm{mL}^{-1} \mathrm{PMA}+120 \mu \mathrm{M} \mathrm{Fe}(\Perp)$; (C5) the relative fluorescence intensities of CDs in the absence and presence of PMA and Fe(॥). (D) Representative images of HeLa cells treated with CDs, NAC, and Fe(॥): (D3) CDs + 1 mM NAC; (D4) CDs + 1 mM NAC + $120 \mu M$ $\mathrm{Fe}\left({ }_{1}\right)$; (D5) the relative fluorescence intensities of CDs in the absence and presence of NAC and Fe(॥). (E) Representative images of HeLa cells treated with CDs and Fe(॥): (E3) only CDs; (E4) CDs + $120 \mu \mathrm{M} \mathrm{Fe(॥);} \mathrm{(E5)} \mathrm{the} \mathrm{relative} \mathrm{fluorescence} \mathrm{intensities} \mathrm{of} \mathrm{CDs} \mathrm{in} \mathrm{the} \mathrm{absence} \mathrm{and} \mathrm{presence} \mathrm{of}$ Fe(॥).

\section{Conclusions}

A high-performance multianalyte fluorescent CDs sensing platform based on the specific recognition of $\mathrm{Fe}(\mathrm{III})$ from $\mathrm{Fe}(\mathrm{II})$ has been successfully developed. With the property of specific response to $\mathrm{Fe}($ III), the system was applied to detect not only
$\mathrm{Fe}(\mathrm{III})$ but also $\mathrm{H}_{2} \mathrm{O}_{2}$ and glucose. The sensitive assays for $\mathrm{Fe}(\mathrm{III})$, $\mathrm{H}_{2} \mathrm{O}_{2}$, and glucose analyses were established with LOD values of $0.25 \mu \mathrm{M}, 0.82 \mu \mathrm{M}$, and $1.71 \mu \mathrm{M}$, respectively. The application of the system in sensing Fe(III) and glucose in human serum showed excellent sensitivity and accuracy. Further, the system can be used to monitor $\mathrm{Fe}(\mathrm{III})$ and $\mathrm{H}_{2} \mathrm{O}_{2}$ in living cells. These 
results demonstrated that the system was promising as an efficient platform for sensing these analytes for clinical diagnosis.

\section{Acknowledgements}

This work was supported by the financial support of the International Science \& Technology Cooperation Program of China (No. 2015DFR40460), National Natural Science Foundation under Grant (No. 81402896, No. 81573390), the National HighTech Research and Development Program of China (863 Program) under Grant (No. 2014AA022303).

\section{Notes and references}

1 T. Walczyk and F. Von Blanckenburg, Science, 2002, 295, 2065-2066.

2 T. A. Rouault, Nat. Chem. Biol., 2006, 2, 406-414.

3 M. W. Hentze, M. U. Muckenthaler, B. Galy and C. Camaschella, Cell, 2010, 142, 24-38.

4 B. D'Autreaux, N. P. Tucker, R. Dixon and S. Spiro, Nature, 2005, 437, 769-772.

5 R. S. Eisenstein, Annu. Rev. Nutr., 2000, 20, 627-662.

6 D. A. Weinstein, C. N. Roy, M. D. Fleming, M. F. Loda, J. I. Wolfsdorf and N. C. Andrews, Blood, 2002, 100, 37763781.

7 W. H. Horl, J. Am. Soc. Nephrol., 2007, 18, 382-393.

8 R. Agarwal, N. Vasavada, N. G. Sachs and S. Chase, Kidney Int., 2004, 65, 2279-2289.

9 G. T. Sucak, Z. A. Yegin, Z. N. Ozkurt, S. Z. Aki, T. Karakan and G. Akyol, Bone Marrow Transplant., 2008, 42, 461-467.

10 J. C. Duvigneau, C. Piskernik, S. Haindl, B. Kloesch, R. T. Hartl, M. Huttemann, I. Lee, T. Ebel, R. Moldzio, M. Gemeiner, H. Redl and A. V. Kozlov, Lab. Invest., 2008, 88, 70-77.

11 S. Altamura and M. U. Muckenthaler, J. Alzheimer's Dis., 2009, 16, 879-895.

12 J. A. Duce, A. Tsatsanis, M. A. Cater, S. A. James, E. Robb, K. Wikhe, S. L. Leong, K. Perez, T. Johanssen, M. A. Greenough, H. H. Cho, D. Galatis, R. D. Moir, C. L. Masters, C. McLean, R. E. Tanzi, R. Cappai, K. J. Barnham, G. D. Ciccotosto, J. T. Rogers and A. I. Bush, Cell, 2010, 142, 857-867.

13 S. Zhang, J. Li, M. Zeng, J. Xu, X. Wang and W. Hu, Nanoscale, 2014, 6, 4157-4162.

14 N. Narayanaswamy and T. Govindaraju, Sens. Actuators, B, 2012, 161, 304-310.

15 C. X. Yang, H. B. Ren and X. P. Yan, Anal. Chem., 2013, 85, 7441-7446.

16 X. Y. Qu, Q. Liu, X. N. Ji, H. C. Chen, Z. K. Zhou and Z. Shen, Chem. Commun., 2012, 48, 4600-4602.

17 J. A. Ho, H. C. Chang and W. T. Su, Anal. Chem., 2012, 84, 3246-3253.

18 J. Zong, X. L. Yang, A. Trinchi, S. Hardin, I. Cole, Y. H. Zhu, C. Z. Li, T. Muster and G. Wei, Biosens. Bioelectron., 2014, 51, 330-335.
19 H. T. Li, Z. H. Kang, Y. Liu and S. T. Lee, J. Mater. Chem., 2012, 22, 24230-24253.

20 S. J. Zhu, Q. N. Meng, L. Wang, J. H. Zhang, Y. B. Song, H. Jin, K. Zhang, H. C. Sun, H. Y. Wang and B. Yang, Angew. Chem., Int. Ed., 2013, 52, 3953-3957.

21 X. T. Zheng, A. Than, A. Ananthanaraya, D. H. Kim and P. Chen, ACS Nano, 2013, 7, 6278-6286.

22 Y. Li, Y. Zhao, H. H. Cheng, Y. Hu, G. Q. Shi, L. M. Dai and L. T. Qu, J. Am. Chem. Soc., 2012, 134, 15-18.

23 B. Shi, Y. Su, L. Zhang, M. Huang, R. Liu and S. Zhao, ACS Appl. Mater. Interfaces, 2016, 8, 10717-10725.

24 Y. Chen, Y. Wu, B. Weng, B. Wang and C. Li, Sens. Actuators, $B, 2016,223,689-696$.

25 A. Sachdev and P. Gopinath, Analyst, 2015, 140, 4260-4269. 26 P. Li, X. Y. Sun, J. S. Shen and B. Liu, RSC Adv., 2016, 6, 61891-61896.

27 G. M. Li, N. Lv, J. L. Zhang and J. Z. Ni, RSC Adv., 2017, 7, 16423-16427.

28 X. Wang, X. Shen, B. Z. Li, G. Y. Jiang, X. M. Zhou and H. J. Jiang, RSC Adv., 2016, 6, 18326-18332.

29 J. Gong, X. Lu and X. Q. An, RSC Adv., 2015, 5, 8533-8536.

30 L. Wang, H. R. Zhang, X. H. Zhou, Y. L. Liu and B. F. Lei, RSC Adv., 2016, 6, 98554-98562.

31 M. J. Bojdys, J. O. Muller, M. Antonietti and A. Thomas, Chemistry, 2008, 14, 8177-8182.

32 J. Yu, N. Song, Y.-K. Zhang, S.-X. Zhong, A.-J. Wang and J. Chen, Sens. Actuators, B, 2015, 214, 29-35.

33 S. Liu, J. Tian, L. Wang, Y. Luo, J. Zhai and X. Sun, J. Mater. Chem., 2011, 21, 11726-11729.

34 S. Liu, J. Tian, L. Wang, Y. Zhang, X. Qin, Y. Luo, A. M. Asiri, A. O. Al-Youbi and X. Sun, Adv. Mater., 2012, 24, 2037-2041.

35 A. Sachdev, I. Matai and P. Gopinath, $R S C A d v ., 2014$, 4, 20915-20921.

36 Y. Q. Dong, H. C. Pang, H. B. Yang, C. X. Guo, J. W. Shao, Y. W. Chi, C. M. Li and T. Yu, Angew. Chem., Int. Ed., 2013, 52, 7800-7804.

37 A. Jaiswal, S. S. Ghosh and A. Chattopadhyay, Chem. Commun., 2012, 48, 407-409.

38 D. Y. Pan, J. C. Zhang, Z. Li and M. H. Wu, Adv. Mater., 2010, 22, 734-738.

39 S. N. Baker and G. A. Baker, Angew. Chem., Int. Ed., 2010, 49, 6726-6744.

40 H. J. Zhang, Y. L. Chen, M. J. Liang, L. F. Xu, S. D. Qi, H. L. Chen and X. G. Chen, Anal. Chem., 2014, 86, 9846-9852. 41 J. Mullay, J. Am. Chem. Soc., 1985, 107, 7271-7275.

42 X. J. Gong, W. J. Lu, M. C. Paau, Q. Hu, X. Wu, S. M. Shuang, C. Dong and M. M. F. Choi, Anal. Chim. Acta, 2015, 861, 7484.

43 Y. L. Zhai, Z. J. Zhu, C. Z. Zhu, J. T. Ren, E. K. Wang and S. J. Dong, J. Mater. Chem. B, 2014, 2, 6995-6999.

44 C. Zhang, Y. Cui, L. Song, X. Liu and Z. Hu, Talanta, 2016, 150, 54-60.

45 W. J. Lu, X. J. Gong, M. Nan, Y. Liu, S. M. Shuang and C. Dong, Anal. Chim. Acta, 2015, 898, 116-127.

46 X. Gong, W. Lu, M. C. Paau, Q. Hu, X. Wu, S. Shuang, C. Dong and M. M. Choi, Anal. Chim. Acta, 2015, 861, 74-84. 
47 M. Zhou, Z. Zhou, A. Gong, Y. Zhang and Q. Li, Talanta, 2015, 143, 107-113.

48 L. Chen, C. Wu, P. Du, X. Feng, P. Wu and C. Cai, Talanta, 2017, 164, 100-109.

49 S. R. Tyagi, M. Tamura, D. N. Burnham and J. D. Lambeth, J. Biol. Chem., 1988, 263, 13191-13198.
50 K. Ishikawa, K. Takenaga, M. Akimoto, N. Koshikawa, A. Yamaguchi, H. Imanishi, K. Nakada, Y. Honma and J. Hayashi, Science, 2008, 320, 661-664.

51 S. J. McQuaker, C. L. Quinlan, S. T. Caldwell, M. D. Brand and R. C. Hartley, ChemBioChem, 2013, 14, 993-1000. 